\title{
CCL2 Gene
}

National Cancer Institute

\section{Source}

National Cancer Institute. CCL2 Gene. NCI Thesaurus. Code C20907.

This gene is involved in inflammatory processes and disease development. 